\title{
ИЗУЧЕНИЕ ГИПОГЛИКЕМИЧЕСКОГО ДЕЙСТВИЯ АМИНАЛОНА НА МОДЕЛИ СТРЕПТОЗОТОЦИН-НИКОТИНАМИД- ИНДУЦИРОВАННОГО САХАРНОГО ДИАБЕТА
}

\author{
М.А. Дубровина, Д.В. Куркин, Д.А. Бакулин, Е.Е. Абросимова, \\ И.Н. Тюренков \\ Лаборатория фармакологии сердечно-сосудистых средств НЦИЛС, ВолгГМУ, \\ 400087, Россия, Волгоград, ул. Новороссийская, 39
}

DOI: 10.19163/MedChemRussia2021-2021-377_E-mail: dubrovina.volgmed@gmail.com

По данным ВОЗ число людей с сахарным диабетом (СД) в мире увеличилось в четыре раза с 1980 года. Рекомендации по лечению СД указывают на целесообразность раннего начала терапии и использования комбинации препаратов, воздействующих на различные патогенетические звенья СД 2 типа (инсулинорезистентность, апоптоз бета-клеток и др.). Для гамма-аминомасляной кислоты (ГАМК) в ряде исследований были отмечены протективные эффекты в отношении бета-клеток, что делает целесообразным исследование противодиабетической активности у различных ГАМК-миметиков с целью создания эффективных комбинаций с гипогликемическими препаратами, предназначенной для профилактики прогрессирования СД 2 типа вследствие гибели бета-клеток [1,2].

Исследование выполнено с использованием модели СД смешанного типа (стрептозотоцин-никотинамид-индуцированный), моделируемой однократной инъекцией никотинамида (230 мг/кг) и стрептозотоцина (65мг/мг). Производные ГАМК (аминалон 300 мг/кг, пикамилон 200 мг/кг и фенибут 25 мг/кг) вводили курсом, после формирования патологии. Противодиабетическую активность ГАМК-миметиков оценивали при проведении перорального теста на толерантность к глюкозе после лечения.

При курсовом введении производных ГАМК животным с стрептозотоцин-никотинамид-индуцированным СД было отмечено улучшение утилизации глюкозы в группе, получавшей аминалон.

Аминалон при курсовом введении улучшает утилизацию глюкозы у животных со стрептозотоцин-никотинамид-индуцированным СД. Полученные эффекты могут быть связаны с протективным действием ГАМК в отношении бета-клеток. Необходимы дальнейшие исследования для выбора гипогликемического препарата для создания рациональной комбинации с ГАМК миметиком.

\section{Литература}

[1] X. Huang, G. Liu, J. Guo, Z Su. Int J Biol Sci. 2018, 14(11), 1483-1496.

[2] Weir G.C., Bonner-Weir S. Cell. 2017, 168(1-2), 7-9. 